\title{
Rates of nitrogen from nitric and ammoniacal sources required by upland rice genotypes originating from Brazil and Colombia
}

\author{
Doses de nitrogênio de fontes nítrica e amoniacal exigidas por \\ cultivares de arroz de sequeiro originárias do Brasil e da Colômbia
}

\author{
Hector Augusto Sandoval Contreras ${ }^{1 *}$; Mario Sandoval Contreras ${ }^{2}$; \\ Renan Ribeiro Barzan ${ }^{1}$; João Pedro Silvestre ${ }^{1}$; Osmar Rodrigues Brito ${ }^{3}$
}

\begin{abstract}
The aim of this study was to evaluate the initial growth, nitrogen $(\mathrm{N})$ uptake, and agronomic efficiency after the use of $\mathrm{N}$ fertilizers in upland rice cultivation. The experiment was conducted in a greenhouse by using pots filled with surface-layer $(0$ to $20 \mathrm{~cm})$ soil collected from the municipality of Jaguapitã, Paraná. The experimental design was completely randomized with 4 replications. A factorial scheme of $5 \times 2$ was used, in which the factors were $5 \mathrm{~N}$ rates $\left(0,25,50,75\right.$, and $\left.100 \mathrm{~kg} \mathrm{ha}^{-1} \mathrm{~N}\right)$ and 2 cultivars of rice (Fedearroz Lagunas [Colombian] and IAPAR- 9 [Brazilian]). The $\mathrm{N}$ sources tested were ammonium sulfate (Experiment I) and calcium nitrate (Experiment II). The following variables were evaluated: number of tillers per pot (NTP), dry mass of the shoots (DMS), N content in the dry mass (NCDM), and agronomic efficiency of $\mathrm{N}$ fertilizer (AEN). The data obtained in the experiments were evaluated using analysis of variance, and mean values were compared using Tukey's test at 5\% significance for rice cultivar effects or adjusted to polynomial regression equations for $\mathrm{N}$ rates. Use of calcium nitrate yielded higher values of NTP, NCDM, and AEN. The cultivar Lagunas showed higher NTP, while IAPAR-9 showed higher DMS. An increase in N rates, for both sources, resulted in the increase of NTP, DMS, and NCDM; however, AEN was decreased.
\end{abstract}

Key words: Ammonium sulfate. Calcium nitrate. Nitrogen fertilization. Oryza sativa. Upland.

\section{Resumo}

O objetivo do trabalho foi avaliar o crescimento inicial, absorção e eficiência agronômica de nitrogênio em cultivares de arroz fertilizado com doses de diferentes fontes de N. Os experimentos foram conduzidos em casa de vegetação, utilizando-se vasos preenchidos com terra coletada da camada superficial de 0 a 20 $\mathrm{cm}$ do município de Jaguapitã, Paraná. O delineamento experimental foi o inteiramente casualizado, com quatro repetições. Os tratamentos testados resultaram de um fatorial $5 \times 2$, em que os fatores foram cinco doses de $\mathrm{N}\left(0,25,50,75\right.$ e $\left.100 \mathrm{~kg} \mathrm{ha}^{-1} \mathrm{de} \mathrm{N}\right)$ e dois cultivares de arroz (Fedearroz Lagunas (Colombiana) e IAPAR-9 (Brasileira)). Como fontes de nitrogênio foram testadas o sulfato de amônio (experimento I) e o nitrato de cálcio (experimento II). As seguintes variáveis foram avaliadas: número de perfilhos por vaso (NPV), massa seca da parte aérea (MSPA), conteúdo de nitrogênio na massa seca (CNMS) e eficiência agronômica do nitrogênio (EAN). Os dados obtidos nos experimentos foram submetidos a análises de variância e as médias comparadas pelo teste de Tukey a 5\% para o efeito de cultivares ou ajustadas a equações de regressão polinomial para o efeito de doses de N. Com relação às fontes, o uso do nitrato de

\footnotetext{
${ }^{1}$ Eng $^{\text {os }} \mathrm{Agr}^{\text {os }}$, Discentes do Curso de Mestrado do Programa de Pós-Graduação em Agronomia, Universidade Estadual de Londrina, UEL, Londrina, PR, Brasil. E-mail: hectorsanco@hotmail.com; renan_barzan@hotmail.com; jp.silvestre08@gmail.com

${ }^{2}$ Eng $^{\mathrm{o}} \mathrm{Agr}^{\mathrm{o}}$, Discente do Curso de Doutorado do Programa de Pós-Graduação em Agronomia, UEL, Londrina, PR, Brasil. E-mail: mariosanco11@hotmail.com

${ }^{3}$ Eng $^{\circ}$ Agro , Prof. Dr., UEL, Londrina, PR, Brasil. E-mail: osmar@uel.br

* Author for correspondence
} 
cálcio proporcionou valores superiores de NPV, CNMS e EAN. A cultivar Lagunas se destaca quanto ao perfilhamento, enquanto IAPAR-9 apresenta maior produção de MSPA. O aumento nas doses de N, em ambas as fontes, eleva o NPV, a MSPA e o CNMS, porém, a EAN é reduzida.

Palavras-chave: Adubação nitrogenada. Oryza sativa. Nitrato de cálcio. Sulfato de amônio. Terras altas.

\section{Introduction}

Rice (Oryza sativa L.) is a staple and important crop for most of the world's population (FISCHER, 1998). Most of the rice-cultivated areas are in Asia (91.1\%), followed by America (5.1\%) (NAYAR, 2014). According to Nokkoul and Wichitparp (2014), upland rice is sown in approximately 20 million hectares, and $30 \%$ of this area is in Latin America; thus, rice contributes significantly to the diet of its residents.

In Brazil, over $60 \%$ of the area cultivated with rice has an upland ecosystem, mainly in the Cerrado regions; however, these areas represent only $40 \%$ of total rice production because of low yield (ALVAREZ et al., 2012; ARTIGIANI et al., 2012). Thus, it is important to increase upland rice yield, considering the great potential to expand rice crop production.

Fageria et al. (2014b) have argued that nitrogen (N) is a nutrient that most limits crop yield in the Cerrado regions. Its complex dynamics in the soil result in many losses, especially by leaching to the deeper layers as $\mathrm{NO}_{3}^{-}$(FAGERIA et al., 2014a) and ammonia volatilization (DUARTE et al., 2007); this reduces fertilization efficiency to less than 50\% (FAGERIA et al., 2014b). Thus, searching for $\mathrm{N}$ supplies that can be used effectively by plants and, consequently, improve their development, is one of the main strategies for enhancing upland rice production.

According to Malavolta (2006), $\mathrm{N}$ is the most required element by plants, and it constitutes 1 to $3 \%$ of the plant material. It is absorbed in inorganic forms as ammonium $\left(\mathrm{NH}_{4}^{+}\right)$and nitrate $\left(\mathrm{NO}_{3}^{-}\right)$, which are provided by fertilizers or organic matter mineralization (QUIRÓSHERRERA; MARTÍNEZ, 2006). $\mathrm{N}$ is associated with fundamental physiological functions and is required to synthesize proteins, nucleic acids, and other cellular constituents (MARSCHNER, 2011); $\mathrm{N}$ is especially important for rice production as it increases the yield components (FAGERIA et al., 2007).

Currently, for upland rice, the main $\mathrm{N}$ sources used are urea and ammonium sulfate because of the cost and availability. According to Blackmer (2000), in the beginning of development, the preferred form of $\mathrm{N}$ uptake by plants is ammoniacal, which was observed by Heinrichs et al. (2006) in rice. However, according to Poletto et al. (2011), high quantities of ammonium in the early stages may affect plant development, reducing the root system, growth, and nutrient absorption. D'Andrea et al. (2004) and Santos et al. (2011) have also reported that nitric N is important for initial growth. There is a hypothesis for different responses by distinct rice genotypes

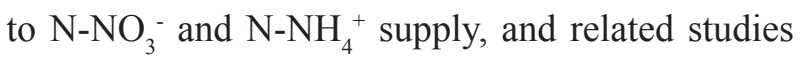
are generally performed using a nutrient solution (ARAÚJO et al., 2012) or flooding (HOLZSCHUH et al., 2009).

Therefore, the aim of this study was to evaluate the agronomic efficiency of nitrogen rates, nutrient absorption, and initial growth of upland rice genotypes originating from Brazil and Colombia when fertilized with nitric or ammoniacal sources.

\section{Material and Methods}

Two experiments were performed in a greenhouse at the Agronomy Department of Londrina State University (UEL), Londrina - PR, Brazil. The surface layer (0 to $20 \mathrm{~cm}$ ) of a distroferric Yellow Latosol (EMBRAPA, 2006) soil was collected from Jaguapitã, north of Paraná State, and placed in plastic pots. 
Before the start of the experiments, liming was performed according to the method reported by Oliveira (2003), to increase the base saturation by up to $60 \%$. Then, the soil was incubated for a period of 20 days, and the humidity was maintained between 70 and $80 \%$ of the maximum water retention capacity (CRUSCIOL et al., 2008). Chemical analysis was performed after incubation and the following results were obtained: $\mathrm{pH} \mathrm{CaCl}$ $=5.2$; organic matter $=1.21 \mathrm{~g} \mathrm{~kg}^{-1} ; \mathrm{Al}=0.05 \mathrm{cmol}_{\mathrm{c}}$ $\mathrm{dm}^{-3} ; \mathrm{Ca}^{2+}=2.73 \mathrm{cmol}_{\mathrm{c}} \mathrm{dm}^{-3} ; \mathrm{Mg}^{2+}=0.83 \mathrm{cmol}_{\mathrm{c}} \mathrm{dm}^{-}$ ${ }^{3} ; \mathrm{K}^{+}=0.9 \mathrm{cmol}_{\mathrm{c}} \mathrm{dm}^{-3} ;(\mathrm{H}+\mathrm{Al})=2.36 \mathrm{cmol}_{\mathrm{c}} \mathrm{dm}^{-3}$; and $\mathrm{V}=61 \%$.

Each plot had a plastic pot with $4 \mathrm{~kg}$ of soil. Before sowing, nutrient solution containing all nutrients, except $\mathrm{N}$, was applied, according to the recommendations suggested by Novais et al. (1991) for conducting the experiments in a controlled environment. In each pot, 8 seeds of rice were sown, and after 10 days, thinning was performed, resulting in 3 seedlings per pot.

The experimental design for both experiments was completely randomized with a factorial scheme of $5 \times 2$ and 4 replications. The first factor was composed of 5 rates of nitrogen $(0,25,50,75$, and $100 \mathrm{~kg} \mathrm{~N} \mathrm{ha}^{-1}$ ) by topdressing at 15 and 30 days after seedling emergence, and the second factor was composed of 2 upland rice genotypes, Fedearroz Lagunas (Colombian) and IAPAR-9 (Brazilian); both have a 120-day cycle. In each experiment, 1 source of nitrogen was used: ammonium sulfate for Experiment I and calcium nitrate for Experiment II.

At 45 days after seedling emergence, the following characteristics were evaluated: dry mass of the shoots (DMS), number of tillers per pot (NTP), N content in the dry mass (NCDM), and agronomic efficiency of $\mathrm{N}$ (AEN). For dry mass evaluation, plant material was collected and dried in a circulating forced air oven at $55^{\circ} \mathrm{C}$ until constant mass was achieved. $\mathrm{N}$ content in the dry mass was determined by using the Kjeldahl method, according to Galvani and Gaertner (2006).
For calculating AEN, an equation proposed by Fageria and Kluthcouski (1980) was used: $\mathrm{AEN}=\left(\mathrm{DMS}_{\mathrm{UN}}-\mathrm{DMS}_{\mathrm{WUN}}\right) / \mathrm{QNA}$, where: $\mathrm{AEN}=$ agronomic efficiency $(\%) ; \mathrm{DMS}_{\mathrm{UN}}=$ dry mass of shoots using $\mathrm{N} ; \mathrm{DMS}_{\mathrm{WUN}}=$ dry mass of the shoots without using $\mathrm{N}$; and QNA = quantity of $\mathrm{N}$ applied.

The data were analyzed using analysis of variance, and the mean values were compared using Tukey's test at 5\% probability for qualitative factors and, when necessary, polynomial regression models were used for the quantitative factor with the software SISVAR v. 5.3 (FERREIRA, 2011).

\section{Results and Discussion}

When performing a comparative analysis of the experiments, it was possible to observe differences between the $\mathrm{N}$ sources with respect to tillering, NCDM, and AEN. For all these characteristics, use of calcium nitrate resulted in higher values (Table 1), which is inconsistent with the findings of Guimarães et al. (2006), who reported that upland rice plants responded more efficiently to the application of ammoniacal $\mathrm{N}$.

Results relative to the study of the rice genotypes and $\mathrm{N}$ rates, within each experiment, are presented separately.

\section{Experiment I (ammonium sulfate)}

The number of tillers varied significantly between the genotypes analyzed, being 99\% higher for cultivar Lagunas (Table 2) and demonstrating the genotypic effect for the referred characteristic. França et al. (2008) also observed genotypic differences with respect to tillering ability of the genotypes IAC-4440 and Comum Branco (16 and 11 tillers per plant, respectively, at 45 days after planting). According to these authors, the ideal number of tillers is 2 to 6 , since part of the excessive tillers becomes unfeasible or infertile and a metabolic sink of dry mass. 
Table 1. Number of tillers per pot (NTP), N content in the dry mass (NCDM), and agronomic efficiency of N (AEN) in rice fertilized with different $\mathrm{N}$ sources.

\begin{tabular}{lccc}
\hline Source of $\mathrm{N}$ & $\begin{array}{c}\text { NTP } \\
\left(\mathrm{n}^{\mathrm{o}}\right)\end{array}$ & $\begin{array}{c}\text { NCDM } \\
\left(\mathrm{mg} \mathrm{pot}^{-1}\right)\end{array}$ & $\begin{array}{c}\text { AEN } \\
(\%)\end{array}$ \\
\hline Calcium nitrate & $11.23 \mathrm{a}$ & $200.50 \mathrm{a}$ & $28.03 \mathrm{a}$ \\
Ammonium sulfate & $10.33 \mathrm{~b}$ & $180.27 \mathrm{~b}$ & $22.40 \mathrm{~b}$ \\
LSD & 0.46 & 6.99 & 1.29 \\
CV\% & 9.51 & 8.21 & 11.40 \\
\hline
\end{tabular}

Means followed by the same letter in the columns do not differ according to Tukey's test at $5 \%$ error probability.

Table 2. Number of tillers per pot (NTP) and dry mass of shoots (DMS) of rice genotypes fertilized with ammonium sulfate.

\begin{tabular}{lcc}
\hline Genotype & $\begin{array}{c}\text { NTP } \\
\left(\mathrm{n}^{\mathrm{o}}\right)\end{array}$ & $\begin{array}{c}\text { DMS } \\
\left(\mathrm{g} \mathrm{pot}^{-1}\right)\end{array}$ \\
\hline IAPAR-9 & $6.90 \mathrm{~b}$ & $12.95 \mathrm{a}$ \\
Lagunas & $13.75 \mathrm{a}$ & $12.11 \mathrm{~b}$ \\
LSD & 0.78 & 0.63 \\
CV\% & 11.83 & 7.85 \\
\hline
\end{tabular}

Means followed by the same letter in the columns do not differ according to Tukey's test at 5\% error probability.

For the production of dry mass in shoots, there was a significant genotypic difference (Table 2), as also observed by França et al. (2008), who reported different rhythms of initial biomass production between rice cultivars. In contrast to tillering, the dry mass of the shoots was slightly higher for IAPAR-9 than for Lagunas. The values obtained may be considered low; however, this is due to the early stage of the plants, since, according to Alvarez et al. (2006), only $20 \%$ of the dry mass in upland rice is accumulated until full tillering.

Production of tillers in the rice plants was higher when the rate of $\mathrm{N}$ from ammonium sulfate was increased, being adjusted to a linear model (Figure 1a). Artigiani et al. (2012) and Larrosa et al. (2001) also found a linear response in tillering with increasing $\mathrm{N}$ rates when urea was used for upland rice and flooded rice, respectively.
Similar to that observed for tillering, dry mass of the shoots demonstrated a linear behavior in accordance with the $\mathrm{N}$ rates (Figure $1 \mathrm{~b}$ ), indicating that these were not sufficient to determine the point of maximum technical efficiency. Different results were obtained by Neves et al. (2004) and Fageria et al. (2008), who observed a quadratic adjustment for the effect of $\mathrm{N}$ rates via urea and ammonium sulfate when they set $120 \mathrm{~kg} \mathrm{~N} \mathrm{ha}^{-1}$ and $80 \mathrm{~kg} \mathrm{~N} \mathrm{ha}^{-1}$ as the maximum point and applied topdressing at 30 and 50 days after emergence, respectively.

For NCDM, a linear effect was observed (Figure 2a), as observed by Larrosa et al. (2001) in flooded rice genotypes by using urea as the $\mathrm{N}$ source. Unlike the other evaluated characteristics, AEN via ammonium sulfate, independent of the genotype, showed a quadratic adjustment with the minimum point estimated as $94.03 \mathrm{~kg} \mathrm{~N}^{-1}$ (Figure 2b). 
Figure 1. Tillering (a) and production of dry mass of shoots (DMS) (b) in upland rice plants as a function of $\mathrm{N}$ rates when applied as ammonium sulfate.
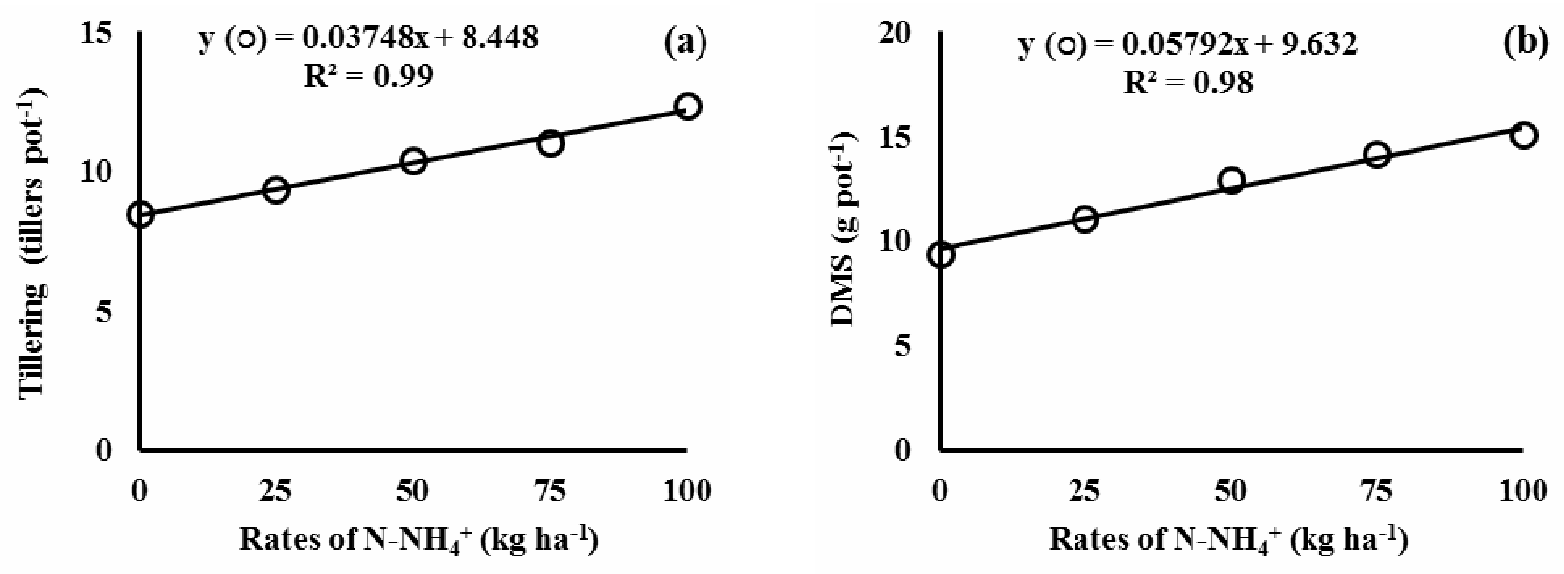

Figure 2. Nitrogen content in dry mass (NCDM) (a) and agronomic efficiency of N (AEN) (b) in upland rice plants as a function of $\mathrm{N}$ rates when applied as ammonium sulfate.

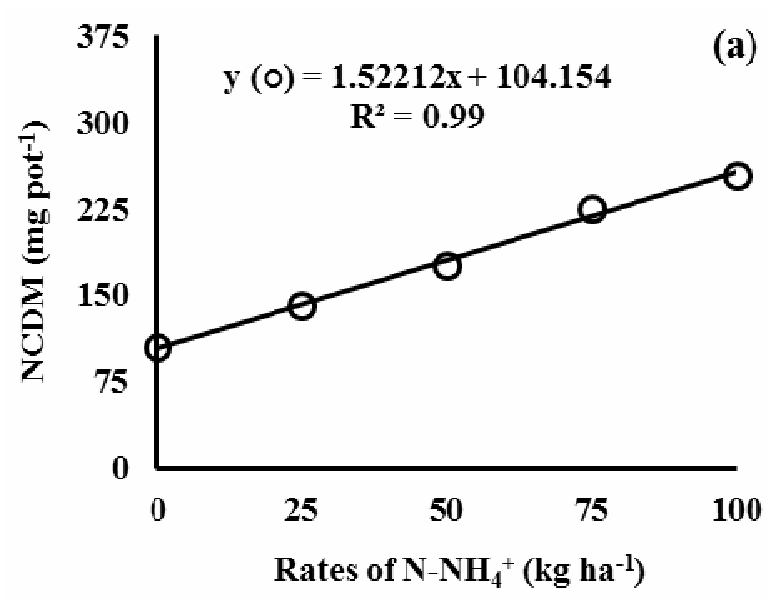

Fidelis et al. (2012) observed that genotypes BRS Bonança, BRS Caiapó, and BRS Primavera responded to topdressing of $\mathrm{N}$ as urea in upland ecosystems in the state of Tocantins. Contreras et al. (2012) worked with different sources of ${ }^{15} \mathrm{~N}$ and reported higher efficiency of $\mathrm{N}$ use with ammonium sulfate when compared with urea and potassium nitrate.

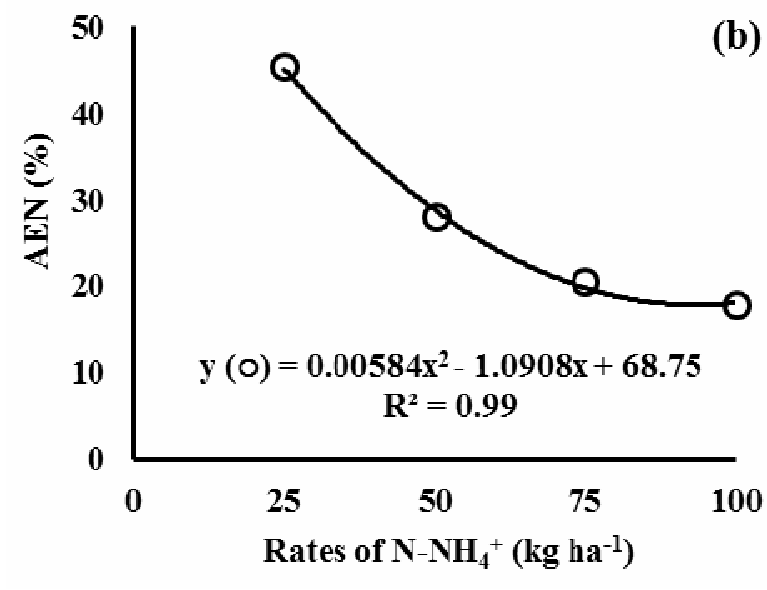

\section{Experiment II (calcium nitrate)}

Similar to the results obtained in Experiment I, rice fertilized with calcium nitrate showed significant differences between genotypes with respect to NTP: cultivar Lagunas showed a higher value (Table 3). 
Table 3. Number of tillers per pot (NTP) and N content in the dry mass (NCDM) of rice genotypes fertilized with calcium nitrate.

\begin{tabular}{lcc}
\hline Genotype & $\begin{array}{c}\text { NTP } \\
\left(\mathrm{n}^{\circ}\right)\end{array}$ & $\begin{array}{c}\text { NCDM } \\
\left(\mathrm{mg} \mathrm{pot}^{-1}\right)\end{array}$ \\
\hline IAPAR-9 & $7.90 \mathrm{~b}$ & $197.34 \mathrm{~b}$ \\
Lagunas & $14.55 \mathrm{a}$ & $203.66 \mathrm{a}$ \\
LSD & 0.50 & 5.78 \\
CV\% & 6.95 & 4.47 \\
\hline
\end{tabular}

Means followed by the same letter in the columns do not differ according to Tukey's test at $5 \%$ error probability.

With respect to NCDM, different behaviors were observed between the rice genotypes, also higher for the cultivar Lagunas (Table 3). These results are similar to those reported by Holzschuh et al. (2009), who indicated differences between genotypes with respect to their ability to take up and accumulate $\mathrm{N}$ in the form of nitrate in shoots.

With respect to the effect of $\mathrm{N}$ rates on tillering, a linear increase of tillers with an increase in $\mathrm{N}$ rates was observed (Figure 3a), demonstrating again that the rates applied were not sufficient to determine the maximum point for the evaluated genotypes. These results differ from those obtained by Araújo et al. (2012), who reported that an increase in nitrate levels increases the production of tillers in a quadratic manner. For $\mathrm{N}$ content, the $\mathrm{N}$ rates presented a linear effect (Figure 3b), which was different from that observed by Avila et al. (2010), who adjusted this characteristic to a quadratic model.

Figure 3. Tillering (a) and $\mathrm{N}$ content in dry mass (NCDM) (b) in upland rice plants as a function of $\mathrm{N}$ rates when applied as calcium nitrate.

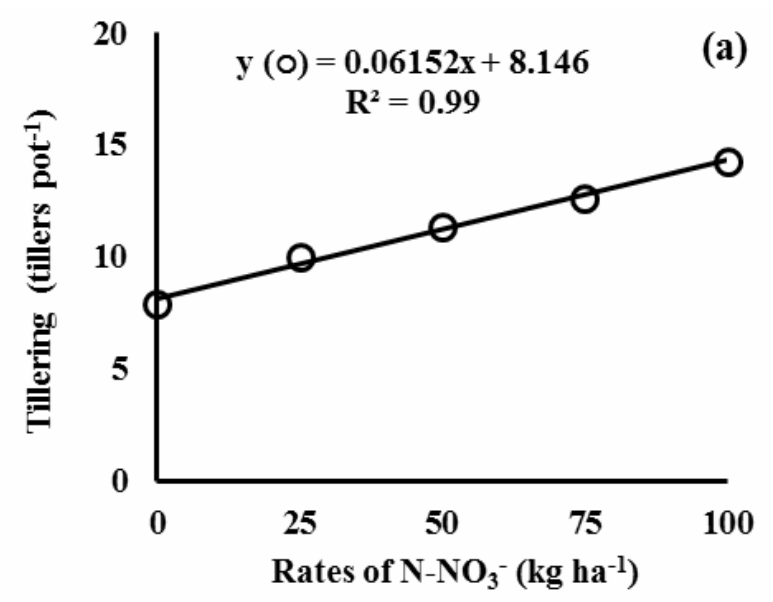

Production of dry mass in the shoots was influenced significantly by the interaction between genotypes and $\mathrm{N}$ rates. Except by the condition of $\mathrm{N}$ fertilization absence, the cultivar IAPAR-9 presented higher DMS within all other $\mathrm{N}$ rates (Figure 4a). Production of this genotype was 16.96

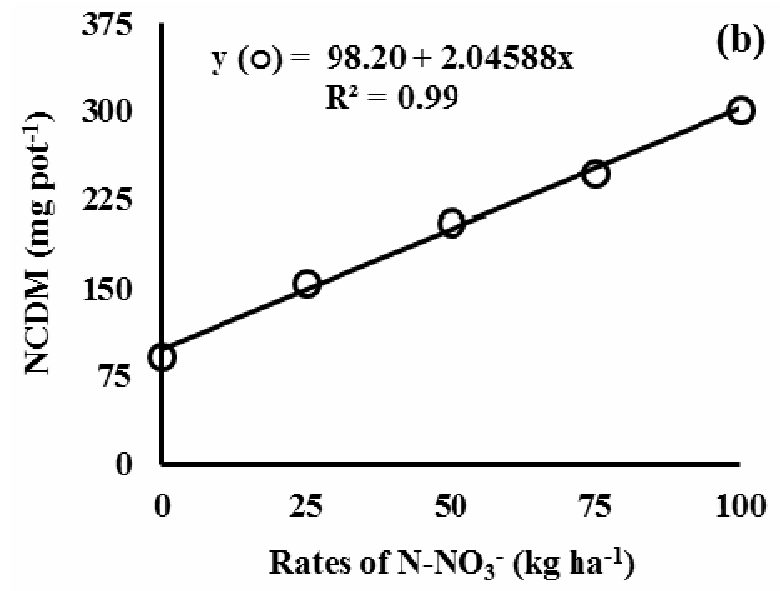

g pot ${ }^{-1}$, and the maximum point was obtained with $99 \mathrm{~kg} \mathrm{~N} \mathrm{ha}{ }^{-1}$. The cultivar Lagunas produced a maximum production of $15.92 \mathrm{~g} \mathrm{pot}^{-1}$, presenting linear adjustment as a function of $\mathrm{N}$ rates (Figure 4a). 
These results differ from that obtained by Araújo et al. (2012), who observed a reduction in dry mass in the shoots for two rice genotypes grown in nutrient solution when $\mathrm{N}$ was applied in the nitric form.

The agronomic efficiency of calcium nitrate was influenced by both factors studied (Figure 4b). The values for AEN were higher for IAPAR-9 only with 25 and $50 \mathrm{~kg} \mathrm{~N} \mathrm{ha}^{-1}$, indicating its higher agronomic efficiency at low $\mathrm{N}$ rates from a nitric source.
By increasing $\mathrm{N}$ rates, it was possible to observe AEN reduction in both genotypes for calcium nitrate, adjusted to decreasing quadratic models, with more pronounced effects for the cultivar Lagunas, which presented a minimum value at $90 \mathrm{~kg} \mathrm{~N}^{-1}$ (Figure 4b). These results are similar to those obtained by Chanh et al. (1981), who verified significant differences between rice groups in nutrient solution with respect to agronomic efficiency in the use of $\mathrm{N}$.

Figure 4. Production of dry mass of shoots (DMS) (a) and agronomic efficiency of N (AEN) (b) as a function of rice genotypes and $\mathrm{N}$ rates applied as calcium nitrate.

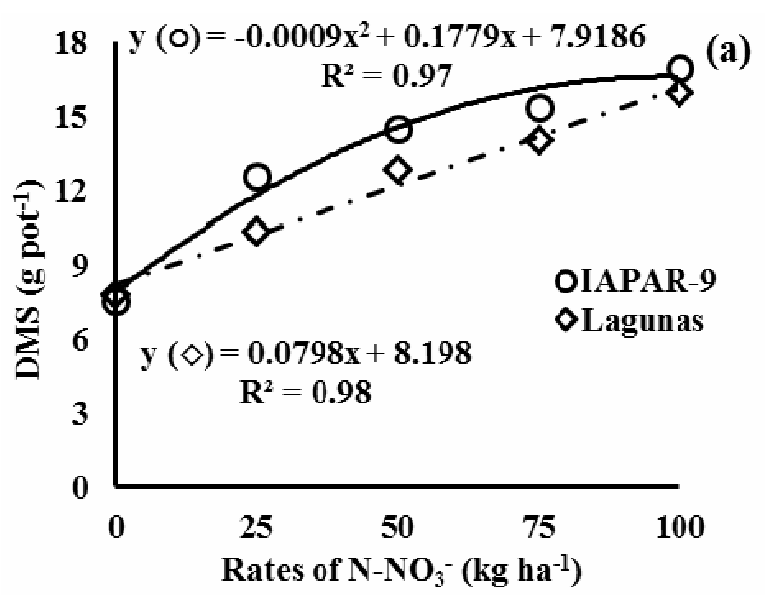

\section{Conclusions}

In rice plants, tillering is increased as a function of $\mathrm{N}$ rates from both sources, nitric and ammoniacal, being higher in the cultivar Lagunas than in IAPAR-9 independently of $\mathrm{N}$ fertilization.

Although the number of tillers was higher in Lagunas, production of dry mass of the shoots was higher in IAPAR-9. This characteristic is still influenced by nitrogen fertilization, being increased as a function of $\mathrm{N}$ rates for both sources used. Calcium nitrate, however, induces a distinct response in the genotypes: quadratic for IAPAR-9 and linear for Lagunas.

The increase in $\mathrm{N}$ rates, for both sources, linearly increases the nutrient content of the genotypes.

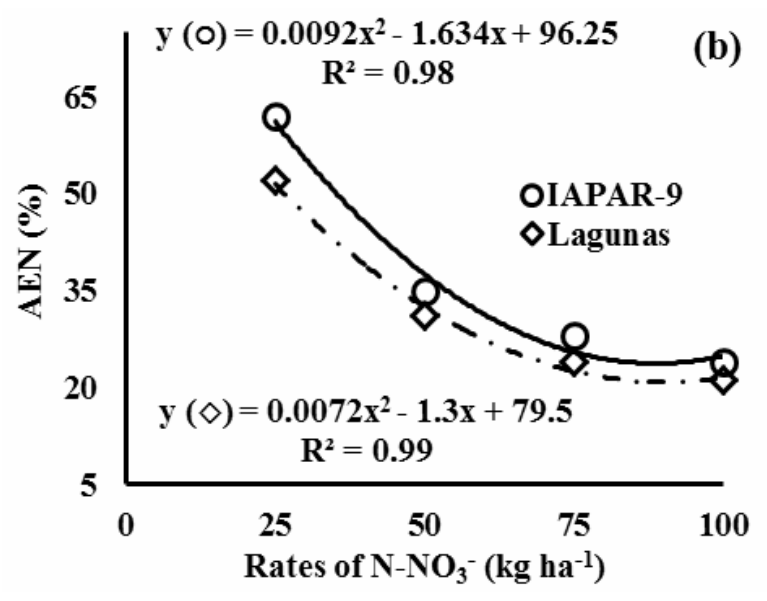

When calcium nitrate was used, the cultivar Lagunas showed higher $\mathrm{N}$ content than IAPAR-9. However, the agronomic efficiency of the $\mathrm{N}$ sources decreases on the basis of increasing $\mathrm{N}$ rates, being higher in IAPAR-9 at low $\mathrm{N}$ rates from nitric source.

Generally, use of calcium nitrate results in higher tillering, nitrogen absorption, and agronomic efficiency $\mathrm{N}$, demonstrating calcium nitrate to be a good alternative for the management of $\mathrm{N}$ supply in upland rice cultivation.

\section{References}

ALVAREZ, R. C. F.; CRUSCIOL, C. A. C.; NASCENTE, A. S. Análise de crescimento e produtividade de cultivares de arroz de terras altas dos tipos tradicional, intermediário 
e moderno. Pesquisa Agropecuária Tropical, Goiânia, v. 42, n. 4, p. 397-406, 2012.

ALVAREZ, R.C.F.; CRUSCIOL, C.A.C.; RODRIGUES, J. D.; AlvareZ, A. C. C. Marcha de absorção de nitrogênio de cultivares de arroz de terras altas com diferentes tipos de plantas. Cientifica, Jaboticabal, v. 32, n. 2, p. 162-169, 2006.

ARAÚJO, J. L.; FAQUIN, V.; VIEIRA, N. M. B.; OLIVEIRA, M. V. C.; SOARES, A. A.; RODRIGUES, C. R.; MESQUITA, A. C. Crescimento e produção do arroz sob diferentes proporções de nitrato e de amônio. Revista Brasileira de Ciência do Solo, Viçosa, MG, v. 36, n. 3, p. 921-930, 2012.

ARTIGIANI, A. C. C. A.; CRUSCIOL, C. A. C.; ARF, O.; ALVAREZ, R. C. F.; NASCENTE, A. S. Produtividade e qualidade industrial do arroz de terras altas em função da disponibilidade hídrica e adubação. Pesquisa Agropecuária Tropical, Goiânia, v. 42, n. 3, p. 340-349, 2012.

AVILA, F. W.; BALIZA, D. P.; FAQUIN, V.; ARAÚJO, J. L.; RAMOS, S. J. Interação entre silício e nitrogênio em arroz cultivado sob solução nutritiva. Revista Ciência Agronômica, Fortaleza, v. 41, n. 2, p. 184-190, 2010.

BLACKMER, A. M. Soil fertility and plant nutrition: bioavailability of nitrogen. In: SUMMER, M. E. (Ed.). Handbook of soil science. New York: CRC Press, 2000. D3-D18 p.

CHANH, T.; TSUTSUMI, M.; KURIHARA, K. Comparative study on the response of Indica and Japonica rice plants to ammonium and nitrate nitrogen. Soil Science and Plant Nutrition, Tokyo, v. 27, n. 1, p. 83-92, 1981.

CONTRERAS, F. S.; MENDES, F. L.; OTTO, R.; MATIAS, G. C. S.; GHIBERTO, P. J.; TRIVELIN, P. C. O. Eficiência agronómica de fuentes de fertilizantes marcados con ${ }^{15} \mathrm{~N}$ en el cultivo de arroz (Oryza sativa). Revista Agropecuaria y Forestal APF, Santo Domingo, v. 1, n. 1, p. 9-14, 2012.

CRUSCIOL, C. A. C.; ARF, O.; SORATTO, R. P.; MATEUS, G. P. Grain quality of upland rice cultivars in response to cropping systems in the Brazilian tropical savanna. Sciencia Agricola, Piracicaba, v. 65, n. 5, p. 468-473, 2008.

D'ANDREA, A. F.; SILVA, M. L. N.; CURI, N.; GUILHERME, L. R. G. Estoque de carbono e nitrogênio e formas de nitrogênio mineral em solo submetido a diferentes sistemas de manejo. Pesquisa Agropecuária Brasileira, Brasília, v. 39, n. 2, p. 179-186, 2004.
DUARTE, F. M.; POCOJESKI, E.; SILVA, L. S.; GRAUPE, F. A.; BRITZKE, D. Perdas de nitrogênio por volatilização de amônia com aplicação de uréia em solo de várzea com diferentes níveis de umidade. Ciência Rural, Santa Maria, v. 37, n. 3, p. 705-711, 2007.

EMPRESA BRASILEIRA DE PESQUISA AGROPECUÁRIA - EMBRAPA. Centro Nacional de pesquisa de solos. Sistema Brasileiro de classificação do solo. 2. ed. Rio de Janeiro: Embrapa Solos, Brasil, 2006. $306 \mathrm{p}$.

FAGERIA, N. K.; CARVALHO, M. C. S.; SANTOS, F. C. Response of upland rice genotypes to nitrogen fertilization. Communications in Soil Science and Plant Analysis, Philadelphia, v. 45, n. 15, p. 2058-2066, 2014a.

FAGERIA, N. K.; KLUTHCOUSKI, J. Metodologia para avaliação de cultivares de arroz e feijão, para condições adversas de solo. Goiânia: EMBRAPA/ CNPAF, 1980. 22 p.

FAGERIA, N. K.; MOREIRA, A.; MORAES, L. A. C.; MORAES, M. F. Nitrogen uptake and use efficiency in upland rice under two nitrogen sources. Communications in Soil Science and Plant Analysis, Philadelphia, v. 45, n. 4, p. 461-469, 2014b.

FAGERIA, N. K.; SANTOS, A. B.; CUTRIM, V. A. Dry matter and yield of lowland rice genotypes as influenced by nitrogen fertilization. Journal of Plant Nutrition, Philadelphia, v. 31, n. 4, p. 788-795, 2008.

Produtividade de arroz irrigado e eficiência de uso do nitrogênio influenciadas pela fertilização nitrogenada. Pesquisa Agropecuária Brasileira, Brasília, v. 42, n. 7, p. 1029-1034, 2007.

FERREIRA, D. F. Sisvar: a computer statistical analysis system. Ciência e Agrotecnologia, Lavras, v. 35, n. 6, p. 1039-1042, 2011.

FIDELIS, R. R.; ROTILI, E. A.; SANTOS, M. M.; BARROS, H. B.; RODRIGUES, A. M. Eficiência quanto ao uso e resposta à aplicação de nitrogênio de cultivares de arroz em solos de terras altas no sul do estado de Tocantins, Safra 2007/2008. Bioscience Journal, Uberlândia, v. 28, n. 3, p. 432-438, 2012.

FISCHER, K. S. Toward increasing nutrient-use efficiency in rice cropping systems: the next generation of technology. Field Crops Research, Amsterdam, v. 56, n. 1-2, p. 1-6, 1998.

FRANÇA, M. G. C. M.; ARAÚJO, A. P.; ROSSIELLO, R. O. P.; RAMOS, F. T. Relações entre crescimento vegetativo e acúmulo de nitrogênio em duas cultivares de arroz com arquiteturas contrastantes. Acta Botanica Brasilica, São Paulo, v. 22, n. 1, p. 43-49, 2008. 
GALVANI, F.; GAERTNER, E. Adequação da metodologia Kjeldahl para determinação de nitrogênio total e proteína bruta. Corumbá: Embrapa, 2006. 9 p. (Circular técnica, 63).

GUIMARÃES, C.; STONE, L.; RODRIGUES, C. Nitrato e amônio em arroz de terras altas. In: CONGRESSO BRASILEIRO DA CADEIA PRODUTIVA DE ARROZ, REUNIÃO NACIONAL DE PESQUISA DE ARROZ, 8. 2., 2006, Brasília. Anais... Santo Antônio de Goiás: Embrapa Arroz e Feijão, 2006. CD-ROM.

HEINRICHS, R.; GAVA, G.; CORAZZA, E.; DUETE, R.; VILLANUEVA, F.; MURAOKA, T. Forma preferencial de absorção de nitrogênio $\left({ }^{15} \mathrm{NH}_{4}^{+}\right.$ou $\left.{ }^{15} \mathrm{NO}_{3}^{-}\right)$ pelas culturas de soja, feijão, arroz e milho. Cientifica, Jaboticabal, v. 34, n. 1, p. 25-30, 2006.

HOLZSCHUH, M. J.; BOHNEN, H.; ANGHINONI, I.; MEURER, E. J.; CARMONA, F. C.; COSTA, S. E. V. G. A. Resposta do arroz irrigado ao suprimento de amônio e nitrato. Revista Brasileira de Ciência do Solo, Viçosa, MG, v. 33, n. 5, p. 1323-1331, 2009.

LARROSA, R. F. M.; MARCHEZAN, E; AITA, C.; CORADINI, J. Z. Eficiência da aplicação de nitrogênio no perfilhamento do arroz em três manejos de irrigação. Ciencia Rural, Santa Maria, v. 31, n. 5, 745-749, 2001.

MALAVOLTA, E. Manual de nutrição mineral de plantas. São Paulo: Agronômica Ceres Ltda, 2006. 631 p.

MARSCHNER, P. Marschner's mineral nutrition of higher plants. $3^{\text {th }}$ ed. Waltham: Academic Press, 2011. $672 \mathrm{p}$.

NAYAR, N. M. Origins and phylogeny of rice. Trivandrum: Elsevier, 2014. 325 p.
NEVES, M. B.; BUZETTI, S.; ARF, O.; SÁ, M. E. Doses e épocas de aplicação de nitrogênio em cobertura em dois cultivares de arroz com irrigação suplementar. Acta Scientiarum: Agronomy, Maringá, v. 26, n. 4, p. 429-435, 2004.

NOKKOUL, R.; WICHITPARP, T. Effect of drought condition on growth, yield and grain quality of upland rice. American Journal of Agricultural and Biological Sciences, New City, v. 9, n. 3, p. 439-444, 2014.

NOVAIS, R. F.; NEVES, J. C.; BARROS, N. F. Ensaio em ambiente controlado. In: OLIVEIRA, A. J.; GARRIDO, W. E.; ARAUJO, J. D.; LOURENÇO, S. Métodos de pesquisa em fertilidade do solo. Brasília: Embrapa-Sea, 1991. p. 189-254.

OLIVEIRA, E. L. Sugestão de adubação e calagem para culturas de interesse econômico no Estado do Paraná. Londrina: IAPAR, 2003. 30 p. (Circular técnica, 128).

POLETTO, N.; MUNDSTOCK, C. M.; GROHS, D. S.; MAZURANA, M. Padrão de afilhamento em arroz afetado pela presença dos íons amônio e nitrato. Bragantia, Campinas, v. 70, n. 1, p. 96-103, 2011.

QUIRÓS-HERRERA, R.; MARTÍNEZ, C. R. Evaluación de la fertilización nitrogenada en arroz inundado. Agronomía mesoamericana, Alajuela, v. 17, n. 2, p. 7885, 2006.

SANTOS, L. A.; SANTOS, W. A.; SPERANDITO, M. V. L.; BUCHER, C. A.; SOUZA, S. R.; FERNANDES, M. S. Nitrate uptake kinetics and metabolic parameters in two rice varieties grown in high and low nitrate. Journal of Plant Nutrition, Philadelphia, v. 34, n. 7, p. 988-1002, 2011. 
